\title{
Honey Bees (Apis mellifera L.) and Pollination Issues: Current Status, Impacts, and Potential Drivers of Decline
}

\author{
Yagya Prasad Paudel ${ }^{1}$, Robert Mackereth ${ }^{2}$, Rodney Hanley ${ }^{1} \&$ Wensheng Qin ${ }^{1}$ \\ ${ }^{1}$ Department of Biology, Lakehead University, Thunder Bay, Canada \\ ${ }^{2}$ Centre for Northern Forest Ecosystem Research, Thunder Bay, Canada \\ Correspondence: Wensheng Qin, Department of Biology, Lakehead University, Thunder Bay, ON, P7B 5E1, \\ Canada. Tel: 1-807-343-8467. E-mail: wqin@lakeheadu.ca
}

Received: March 10, 2015 Accepted: April 8, 2015 Online Published: May 15, 2015

doi:10.5539/jas.v7n6p93 URL: http://dx.doi.org/10.5539/jas.v7n6p93

\begin{abstract}
European honey bees (Apis mellifera L.) are important pollinators of many fruits, nuts, vegetables and field crops. Honey bees also pollinate different wild flowering plants and help to maintain the ecosystems. Currently, these pollinators are facing a number of threats including habitat destruction, pesticides, mites, parasites and loss of genetic diversity. Because of the decline in their number, there is a great loss of ecological services which impacts the world's economy. This review of honey bee and pollination issues highlights the need of protection and conservation of these important pollinators. Research is required to quantify the synergistic effects of potential drivers for current colony loss and to identify the ecotypes and native species of honey bees which are more resistant to pests, pathogens and pesticides.
\end{abstract}

Keywords: honey bees, decline, pollination, economy

\section{Importance of Honey Bees (Apis mellifera L.) as Pollinators}

Flowering plants are very important to wildlife and humankind as they provide food, fiber and shelter (National Research Council, 2007). For the production of seeds, pollination is an essential step in the reproductive process of the world's nearly 300,000 species of flowering plants (Kevan \& Viana, 2003). With the exception of grain crops and some vegetables, the major proportion of the global crop production mainly depends on biotic pollination (Klein et al., 2007; Ollerton et al., 2011). Insect mediated pollination provides direct and indirect benefits to human societies (Fisher et al., 2009) because insect pollination contributes to the yields of 75 percent of globally important crop species (Klein et al., 2007) including numerous wild plant species (Ollerton, Winfree, $\&$ Tarrant, 2011). One third of the food is derived from plants that are either dependent on or benefit from insect pollination (Oldroyd \& Nanork, 2009), especially honey bees (Richards, 2001).

Bees represent the majority of insect pollinators (Kevan \& Viana, 2003). There are about 17,000 described and 20,000 to 30,000 total estimated bee species in the world (National Research Council, 2007). The Food and Agriculture Organisation of the United Nations (FAO) estimates that out of some 100 crop species which provide $90 \%$ of food worldwide, 71 are bee-pollinated (http://www.fao.org/ag/magazine/0512sp1.htm). The European honey bee (Apis mellifera L.) is an important species of bees which pollinates a number of agricultural crops worldwide (Le Conte \& Navajas, 2008; Klein et al., 2007; Rader et al., 2009) and have often been credited with pollination services that are actually performed by other bee species also (Parker, Batra, \& Tependino, 1987; Richards, 1996). The role played by honey bees as pollinators also contributes to maintain biodiversity because there is a positive correlation between plant diversity and pollinator diversity (Heithaus, 1974; Del Moral \& Standley, 1979). European honey bees have been managed along with other bees like eastern honey bees (Apis cerana F.), bumble bees such as Bombus terrestris L., solitary gregarious species such as leafcutter bees (Megachile rotundata F.) and mason bees (Osmia spp.) for crop pollination (Delaplane \& Mayer, 2000). Wild and managed pollinators may have complementary behavioural relationships thus increasing the efficiency of pollination (Klein, Steffan-Dwenter, \& Tscharntke, 2003) because the pollination by wild pollinators may be as important as that of managed pollinators for agricultural production (Veddeler, Olschewski, Tscharntke, \& Klein, 2008; Klein, Steffan-Dwenter, \& Tscharntke, 2003).

By collecting pollen and nectar from flowers, honey bees transfer pollen of most of the world's plants, providing 
an economically valuable pollination service to crops. According to Gallai, Salles, Settele, and Vaissiere (2009), the contribution of bees (mainly honey bees) and other insects to worldwide crop production for human food is about $\$ 190$ billion each year as honey bees pollinate different types of crops (Table 1). The United States Department of Agriculture (USDA) also reports that honey bees provide pollination services for a number of food crops like almonds, apples, grapefruits, soybeans, strawberries (Del Moral \& Standley, 1979; Williams, 1994). The bee pollinated agricultural crops, fruits and vegetables are valued at USD 20 billion a year in North America (Gallai, Salles, Settele, \& Vaissiere, 2009; Klein et al., 2007; Morse \& Calderone, 2000). Estimates by Canadian researchers on the annual value of honey bee pollination to Canadian agriculture have ranged from CAD 443 million to 1.2 billion ( USD 413 million-1.12 billion; Winston \& Scott, 1984). In Australia, the annual benefits amounted to AUD 156 million ( USD 147 million; Gill, 1990) while in US, benefits were estimated at USD 1.6 to 40 billion (Levin, 1983; Robinson, Nowogrodzki, \& Morse, 1989; Morse \& Calderone, 2000; E. E. Southwick \& Jr L. Southwick, 1992).

Table 1. Crops dependent on bee pollination

\begin{tabular}{llll}
\hline Crops & $\%$ Bee Pollination & Crops & $\%$ Bee Pollination \\
\hline Almonds & 100 & Cucumber & 90 \\
Avocado & 100 & Pumpkin & 90 \\
Blueberry & 100 & Apricot & 70 \\
Broccoli & 100 & Plum and Prune & 70 \\
Carrot & 100 & Strawberry & 70 \\
Cauliflower & 100 & Pear & 50 \\
Celery & 100 & Watermelon & 40 \\
Onion & 100 & Brussels sprouts & 30 \\
Apples & 90 & Cabbage & 30 \\
Asparagus & 90 & Bean & 10 \\
Cherries & 90 & Lettuce & 10 \\
\hline
\end{tabular}

Source: Modified from Gill (1990).

\section{Current Status and Trends of Honey Bee Loss}

The number of honey bees is decreasing showing a trend towards future pollinator shortage (Bauer \& Wing, 2010). In an effort to increase crop yield, honeybees, bumblebees and a few other bee species are purchased or rented by farmers in many countries (McGregor, 1976; Free, 1970; Olmstead \& Wooten, 1987; Robinson, Nowogrodzki, \& Morse, 1989; Dag, Zipori, \& Pleser, 2006).

In 2006, the beekeepers in US observed a mysterious disappearance of managed honey bees, which received a widespread public attention. Researchers have termed this phenomenon Colony Collapse Disorder (CCD), a multifactorial syndrome which has been leading to low number of adult and immature bees (van Engelsdorp, Underwood, Caron, \& Hayes, 2007). The United States and other European countries are currently spending millions of dollars to investigate the potential reasons of the decline in honey bee numbers and to develop mitigation strategies (Pettis \& Delaplane, 2010). The annual colony losses have created problems for both beekeepers and bee-pollination services which may increase rental fees for pollinators (National Research Council, 2007). In North America, the number of managed hives has decreased by 50 percent since the 1950s (Spivak, Mader, Vaughan, \& Euliss, 2010). A report by FAO indicates that in the period between 1961 and 2007, the number of managed colonies decreased in Europe (26.5\%) and North America (49.5\%), Asia (42.6\%), Africa (13.0\%), South America (86\%), and Oceania (39\%). Figure 1 also shows the decline in honey bee hives over the years from 1990 to 2011 in different continents. 


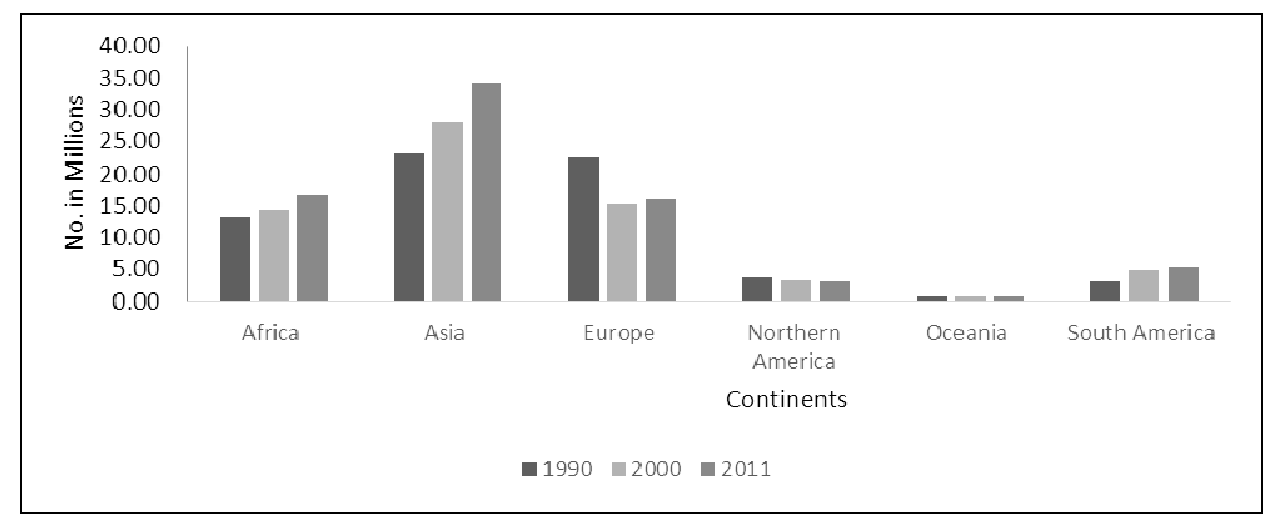

Figure 1. Honey bee hives (Data from FAO 2013)

There are reports of declines of managed pollinators (honey bees) throughout the world (van Engelsdorp \& Meixner, 2010; National Research Council, 2007; Potts et al., 2010). Similarly, elevated colony losses have been reported from Europe (Crailsheim, Brodschneider, \& Neumann, 2009; Potts et al., 2009), the Middle East (Haddad, Bataeneh, Albaba, Obeid, \& Abdulrahman, 2009), including countries like Austria (Brodschneider \& Crailsheim, 2010), Denmark (Vejsnaes, Nielsen, \& Kryger, 2010), England (Aston, 2010), France (Chauzat et al., 2010), Greece (Bacandritsos et al., 2010), Italy (Bortolotti et al., 2010), the Netherlands (Zee, 2010), Norway (Dahle, 2010), Poland (Topolska et al., 2010), Scotland (Gray, Peterson, \& Teale, 2010), Bulgaria (Ivanova \& Petrov, 2010), Croatia (Gajger, Vugrek, Grilec, \& Petrinec, 2010), Bosnia and Herzegovia (Santrac, Granato, \& Mutinelli, 2010), Canada (Currie, Pernal, \& Guzman-Novoa, 2010) and the USA (Ellis, Evans, \& Pettis, 2010; van Englesdorp \& Mexiner, 2010). This can be demonstrated by Figure 2 which shows the percentage of honey bee colony winter loss in different countries in the year 2009/2010.

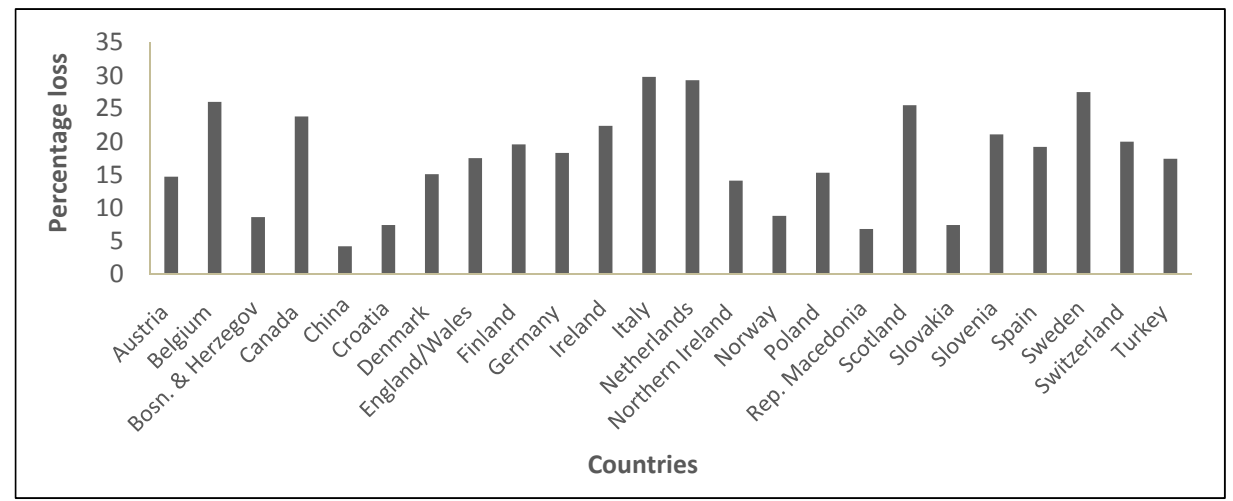

Figure 2. Percentage of colony winter losses in 2009/2010 in several countries

(Cited from Van der Zee et al., 2012)

\section{Impacts of Honey Bee Decline on Ecology and Economy}

Honey bees as pollinators play an important role in maintaining an ecosystem, when we lose these pollinators, it leads to the collapse of other ecological components (Kearns \& Inouye, 1997). Honey bees remain the most important managed pollinators for most crop monocultures worldwide (McGregor, 1976; Delaplane \& Mayer, 2000). The effect of these pollinators decline is associated with decreased crop production (Bauer \& Wing, 2010) leading to the loss in ecological components and economy. The ongoing trend of honey bee decline throughout the world have brought attention to the world food security (Westerkamp \& Gottsberger, 2002; Holden, 2006). The reports of pollinator crisis are mainly the declines of crop-pollinating honey bees in North America, and bumble bees and butterflies in Europe (Ghazoul, 2005) which have been shown by the reports of decreased production of world's crops. In addition to pollination, honey bees also provide benefits for the plants they visit by the deposition of available nitrogen from their frass during foraging (Mishra, Alfik, Cabrea, Delaplane, \& Mowrer, 2013) and they do not show any detrimental impacts on population abundances of any native animals or 
plants (Huryn, 1997). They contribute to the biodiversity of many ecosystems while pollinating a variety of wild flowers (Corbet, Williams, \& Osborne, 1991). The International Union for Conservation of Nature (IUCN) predicts a global loss of 20,000 flowering plant species within the next few decades; which will lead to the decline of the dependent pollinators like honey bees (Heywood, 1995). Also, the pollinator loss ultimately results in the decline of plant biodiversity (Biesmeijer et al., 2006; Thomas et al., 2004; Carvell et al., 2006, Pauw \& Hawkins, 2011).

Now, many nations are concerned about the recent declines of these pollinators. The global pollination crisis currently threatens agricultural productivity and has drawn intense interest among scientists, politicians, and the general public (Aizen, Garibaldi, Cumningham, \& Klein, 2008; Holden, 2006). The farmers are aware of the economic benefit of honey bees pollination and they have started for colony rental of honey bees in the US (Sumner \& Boriss, 2006) and Europe (Carreck, Williams, \& Little, 1997). Because of their reduced number, the prices of honey bee colony rentals for pollination services are growing dramatically over the last few years (Burgett, Daberkow, Rucker, \& Thurman, 2010; Caron, 2010).

The trend of declining honey bee shows that the value of pollination services has been significantly higher than current market prices for commercial pollination (Allsopp, De Lange, \& Veldtman, 2008). Current decline in honey bees and other pollinators could seriously threaten the continued production of insect pollinated crops (Calderone, 2012). Hence, they are vital for economic benefits derived from sustainable agriculture and for food security. The current decline of honey bee populations emphasize the need to assess the potential loss in terms of economic value that may result from this trend. As a consequence of these pollinators decline, there will be a direct impact on economic losses by reduced crop yields as well as the lower productivity in the ecosystems. The main reason for crop yield reduction is due to pollinator's scarcity in combination with other environmental factors leading to reduced production of fruits, vegetables and nuts (Table 2).

Table 2. Percent change (negative) in value of production of select crop sectors due to global pollinator loss

\begin{tabular}{lllllll}
\hline & Africa & Asia & Europe & North America & South America & Oceania \\
\hline Fruits & 18.54 & 30.25 & 15.26 & 43.07 & 27.55 & 29.02 \\
Vegetables & 2.07 & 5.98 & 3.33 & 6.81 & 6.99 & 4.21 \\
Nuts & 21.69 & 39.72 & 23.50 & 13.40 & 19.23 & 26.12 \\
\hline
\end{tabular}

Source: Bauer and Wing (2010).

\section{Potential Drivers of Honey Bees Declines}

Recently the honey bees' population is decreasing rapidly which may be due to agricultural intensification, habitat alteration or fragmentation, pathogens, lack of nutrition, pesticides and the loss of genetic diversity (van Engelsdorp \& Meixner, 2010; Cunningham, 2000; Kearns \& Inouye, 1997; Ingram, Nabhan, \& Buchmann, 1996; Cane, 2001). Still no records have been reported on the impacts of anthropogenic disturbances on honey bee abundance and species richness (Steffan-Dewenter, Potts, \& Packer, 2005; Winfree, Aguilar, Vazquez, LeBuhn, \& Aizen, 2009). Environmental factors like weather conditions, availability of nesting sites, food sources and chronic exposure to insecticides might cause CCD-like symptoms (Oldroyd, 2007). Similarly, the pathogens and parasites which have been demonstrated to be involved in colony losses in different regions of the world are considered current threats to honey bees and beekeeping (Genersch, 2010b). The possible causes of honey bee decline are as follows;

\subsection{Habitat Fragmentation, Loss and Degradation}

Degradation and discontinuity of habitats are responsible for changing pollinator populations (Thomas et al., 2004) because these activities cause genetic erosion by reducing gene flow and increase the chance of populations and species extinction (Barrett, Kohn, Falk, \& Holsinger, 1991). Naug (2009) reported that nutritional stress due to habitat loss and foraging resources cause diseases and stress on honey bees and may cause collapse of colonies. Fragmentation and degradation of habitats can be detrimental to bee populations including honey bees (Rathcke, 1993; Kremen, Williams, \& Thorp, 2002; Steffan-Dewenter, Klein, Gaebele, Alfert, \& Tscharntke, 2006; Cane, Minckley, Kervin, Roulston, \& Williams, 2006) due to the loss or dissociation of important resources for food and nesting (Hines \& Hendrix, 2005; Potts et al., 2005). Habitat loss might be one of the biggest factors impacting honey bee declines and the agricultural landscape changes after the Second 
World War (Winfree, Aguilar, Vazquez, LeBuhn, \& Aizen, 2009). Although, the pollinators including honey bees have been affected negatively with the loss of habitats when the proportion of semi-natural areas have decreased (Kremen, Williams, Bugg, Fay, \& Thorp, 2004), there are no more reports of honey bee colony loss due to habitat loss. So, the loss in habitat is not a major driver for the recent colony loss.

\subsection{Parasites and Diseases}

\subsubsection{Viral Pathogens}

According to Evans and Schwarz (2011), 20 positive-strand RNA viruses infect honey bees which are mainly related to the families of Dicistroviridae and Iflaviridae. Until the introduction of honey bee mite Varroa destructor, the viral pathogens were generally considered harmless (Genersch \& Aubert, 2010) but later on, viruses have been suspected as causal agents of possible colony losses (Berthoud, Imdorf, Haueter, Radloff, \& Neumann, 2010; Carreck, Ball, \& Martin, 2010; Martin, Ball, \& Carreck, 2010).

It appears that Varroa acts both as disseminator and activator of some viruses like acute bee paralysis virus (ABPV), Kashmir bee virus (KBV) and Israeli acute paralysis virus (IAPV). Deformed wing virus (DWV) is a member of the Iflaviridae family and appears not only to be vectored by Varroa but also to replicate within the mite (Genersch \& Aubert, 2010). DWV mainly causes covert, symptomless infections (Hails, Ball, \& Genersch, 2008) and is transmitted vertically through drones and queens or horizontally through larval food (De Miranda \& Fries, 2008; Yue, Schroder, Gisder, \& Genersch, 2007). When transmitted to pupae through V. destructor, it causes infection resulting mainly deformed wings with other effects like shortened and bloated abdomen (Ball \& Allen, 1988; Bowen-Walker, Martin, \& Gunn, 1999; Yang \& Cox-Foster, 2007) leading to the death of bees within less than $67 \mathrm{~h}$ after emergence (Yang \& Cox-Foster, 2007). DWV has been reported as a potential cause for colony loss because it can act independently of Varroa mites (Highfield et al., 2009). Di Prisco et al. (2011) showed that the low temperature of winter increased the virus infection in honey bees and that the severity of DWV infection was positively correlated with $V$. destructor density. They also showed that host conditions are important on outcome of DWV showing honey bee morality rate.

IAPV has been identified as a marker or secondary agent of CCD (Cox-Foster \& van Engelsdorp, 2009) and anti-viral treatment using IAPV-specific RNAi was able to silence IAPV and to reduce the symptoms of CCD (Maori et al., 2009). IAPV is prevalent in the Middle East, Australia and the USA but less frequently found in Europe (De Miranda, Cordoni, \& Budge, 2010). Because of this, IAPV has been found to be associated with colony losses in USA (Cox-Foster et al., 2007) but so far not in Europe (Genersch, 2010b). The DWV should be considered as a major virus causing the loss of honey bee colonies.

\subsubsection{Bacterial Pathogens}

There are two main bacterial pathogens of honey bees and both are pathogenic to larvae but not to adult bees: Melissococcus plutonius, causing European Foulbrood (Bailey, 1956, 1957) and Paenibacillus larvae, causing American Foulbrood (Genersch et al., 2006; Genersch, 2010a). P. larvae is a spore forming bacteria which makes control more difficult than M. plutonius, which is not a spore forming bacterium. The bacteria enter the larvae through ingestion and proliferate in the larval midgut, assimilating much of the larval food and the infected larvae die from starvation (Bailey, 1983). There are few reports of colony loss due to bacterial pathogens around the world.

\section{1) American Foulbrood}

American foulbrood (AFB) is a bacterial disease of the bee brood. It is a notifiable disease in many countries. It is highly contagious, easily and rapidly spread within a colony and among colonies. Such colonies with AFB should be destroyed to prevent the disease from spreading further. AFB has had the greatest impact on the apiary industry. In 2000, the annual economic loss attributed to AFB infection in the US was $\$ 5$ million (Eischen, Graham \& Cox, 2005). It is considered to be more virulent than European foulbrood.

\section{2) European Foulbrood}

European foulbrood (EFB) has been reported from across every continent that honey bees inhabit (Matheson, 1993) and currently appears particularly prevalent and dramatically increasing in the UK (Wilkins, Brown, \& Cuthbertson, 2007; Tomkies et al., 2009) and Switzerland (Forsgren, 2010; Belloy et al., 2007; Roetschi, Berthoud, Kuhn, \& Imdorf, 2008). The bacteria cause the asymptomatic colonization of honey bee at first, until the time bees start to show symptoms of infections. Later on, bee larva die due to infection (Mckee, Goodman, \& Hornitzky, 2004). EFB has not been reported from different countries and thus it is not believed to be a major factor to explain widespread colony loss. 


\subsubsection{Fungal Pathogens}

\section{1) Nosema spp.}

Two species of Nosema have been found to cause diseases in honeybees: Nosema apis and N. ceranae. Nosema spp. invade the digestive cells lining the mid-gut of the bee. Nosema spores may be transmitted by a variety of routes including honey and pollen (Higes et al., 2008). N. ceranae, a microscopic fungus which causes the most common adult bee disease Nosemosis (type C) (Paxton, 2010; Santrac, Granato, \& Mutinelli, 2010) is a more recent transfer from the Asian honeybee A. cerana and was first reported in Europe in 2005 (Higes, Martin, \& Meana, 2006; Antunez et al., 2009; Botias et al., 2012). N. ceranae was confirmed in many European countries (Paxton, Klee, Korpela, \& Fries, 2007) including Canada and USA (Williams, Shafer, Rogers, Shutler, \& Stewart, 2008). N. ceranae infects A. mellifera populations elsewhere in the world (Chen, Evans, Smith, \& Pettis, 2008; Giersch, Berg, Galea, \& Hornitzky, 2009; Higes, Martin, \& Meana, 2006, Huang, Jiang, Chen, \& Wang, 2007; Invernizzi et al., 2009, Klee et al., 2007). Nosema spores which are present in faeces but can also be found in pollen, infect adult bees upon ingestion (Higes et al., 2008). The spores germinate and infect the cells of midgut, releasing new spores into the gut lumen (Fries, 2010). N. apis causes nosemosis (type A), the clinical outbreak which is characterized mainly by dysentery, whereas, $N$. ceranae causes death of individuals and colonies without any visible symptoms (Higes et al., 2008). However, Traver, and Fell (2011) found no significant correlation between Nosema infection and colony strength even the infection prevalence of $N$. ceranae was $69.3 \%$. Thus, Nosema has not been found responsible for loss of honey bees in all the cases.

\subsubsection{Parasites}

\section{1) Varroa mite}

Varroa mites could be the main reason for recent decline of honey bee colonies (Guzman-Novoa et al., 2010). $V$. destructor, causes a disease of honey bees called varrosis (Carreck, Ball, \& Martin, 2010; Dahle, 2010; Martin, Ball, \& Carreck, 2010) which appears from autumn to early spring during the overwintering phase. It causes general weakening and often complete losses of colonies. It is also a vector of a number of viruses which affect honey bee health and shorten the lives of infected bees under certain conditions. $V$. destructor does not have any free living life stages and completes all the life stages on honey bees. When a bee has been infested by this ectoparasite, it takes a longer time to return or even does not return to the colony (Kralj, Brockmann, Fuchs, \& Tautz, 2007; Kralj \& Fuchs, 2006). The V. destructor mite has an impact on the bee's immune system and on the susceptibility of honey bees towards various pathogens (Gregory, Evans, Rinderer, \& De Guzman, 2005; Yang \& Cox-Foster, 2005). V. destructor has been found to be responsible for colony losses especially in combination with virus infections (Ball, 1983; Ball \& Allen, 1988; Delaplane \& Hood, 1999; Hung, Adams, \& Shimanuki, 1995; Martin, 2001; Todd, De Miranda, \& Ball, 2007). So, V. destructor is responsible for the colony loss of $A$. mellifera.

\subsection{Pesticides}

There are different pesticides and other chemicals which can poison the honey bees influencing their health. These chemicals also affect plants in their productivity and eliminate nectar sources for pollinators and also deplete nesting materials (mainly flowers) for honey bees (Nabhan \& Buchmann, 1996). The pesticides mainly neonicotinoids are responsible for the possible decline of honey bees (Cresswell \& Thompson, 2012; Bernal et al., 2010). Neonicotinoids cause toxic effects as well as synergistically reinforce infectious agents such as $N$. ceranae which together can produce colony collapse (van der Sluijs et al., 2013). However, in some countries neonicotinoids are not regarded as the major risk factors associated with current colony losses (Fairbrother, Purdy, Anderson, \& Fell, 2014) because there are no direct links between neonicotinoids and CCD (Hopwood et al., 2012). Also, dietary neonicotinoids do not cause the honey bee declines (Cresswell \& Thompson, 2012).

In addition to neonicotinoids, other pesticides are also found to have negative effect on health of honey bees. Increased probability of Nosema infection was reported in bees that consumed pollen with a higher fungicide load (Pettis, Lichtenberg, Andree, Stitzinger, \& Rose, 2013). Likewise, the residues of insecticide imidacloprid in nectar and pollen at high levels may be dangerous to bees (Laurent \& Rathahao, 2003; Chauzat et al., 2006). Widespread losses of colonies in France is due to imidacloprid (Laurent \& Rathahao, 2003). Similarly, other pesticides "acaricides" have also been found harmful for bees' health (Harz, Muller, \& Rademacher, 2010). The acaricidal substances that were intentionally brought into the hives to control $V$. destructor are the most reported pesticides residues in honey bee colonies (Chauzat et al., 2006; Mullin et al., 2010; Johnson, Ellis, Mulli, \& Frazier, 2010; Bernal et al., 2010). In most of the cases, the major pesticide contaminants in hives are the ones used by beekeepers and their residues have shown a number of sub lethal effects. The sub lethal effects of pesticides can have indirect effects including on foraging activity (Wu, Anelli, \& Sheppard, 2011). 
In Europe, a proposed pesticide ban has gathered scientific support with some additional field studies (Cressey, 2013). Pesticides and the techniques to use them represent one of the major uncertainties around the decline in honey bee numbers (Maini, Medrzycki, \& Porrini, 2010). Some pesticides cause a wide range of sub lethal effects on honey bees with different traits and severities. It is difficult to observe sub lethal effects of pesticides on the health of honey bee colonies. The sub lethal pesticide residue concentrations found in nectar, pollen and bee bread are considered a potential factor resulting in delayed adverse effects on bee health (Chauzat et al., 2010). However, Bernal et al. (2010) found no correlation between sub lethal levels of pesticide residues in bee hives and colony mortality. There are major weaknesses of regulatory risk assessment and marketing authorisation of pesticides, particularly for neonicotinoids (Maxim \& van der Sluijs, 2013).

In addition, there are reports of spray applications of pesticides in different countries, usually due to misuse of products, resulting in the contamination of nectar and pollen (Barnett, Charlton, \& Fletcher, 2007; Thompson \& Thorbahn, 2010). Exposure to neurotoxicants like imidacloprid in honey bee and their role with CCD remains to be determined (Mullin et al., 2010). Further field research would be needed to determine the sub lethal effects of neonicotinoids in bee health.

\subsection{Diet and Honey Bees}

Nutrition plays an important role to maintain the health and honey bee colonies (Brodschneider \& Crailsheim, 2010). If honey bees have difficulty accessing sufficient pollen sources for all their essential amino acids they may be weakened and make them be more vulnerable to various pathogens and diseases. To maintain health, foraging bees need a variety of sources of natural nectar and pollen to prevent nutritional deficiency and to strengthen immune defences (Brodschneider \& Crailsheim, 2010; Alaux, Ducloz, Crauser, \& Le Conte, 2010; Pedersen \& Omholt, 1993). Protection programs aimed at maintaining or enhancing plant diversity may help to provide better forage to bees and reduce the risk of malnutrition.

\subsection{Relationship of Genetically Modified (GM) Crops and Honey Bee Decline}

Initially the development of Genetically Modified Organisms (GMOs) was aimed to prevent the plants against the potentially adverse effects of pesticides and pests. The GMO crops with insecticidal properties could have a negative, sub-lethal, effect on bees. However, this concern of negative effect of GMOs have not been verified (Marvier, McCreedy, Regetz, \& Kareiva, 2007; Duan, Marvier, Huesing, Dively, \& Huang, 2008). The worker bees and colonies fed pollen from genetically modified Bacillus thuringiensis (Bt) corn did not have increased rates of mortality (Rose, Dively, \& Pettis, 2007). To date, no strong evidence exists that GM crops cause acute toxicity to honey bees (Huang, Hanley, Pett, Langenberger, \& Duan, 2004).

\subsection{Weather and Climate in Honey Bee Decline}

Climate variations have an important role for bee colonies. Extended periods of cold, rainy, and hot weather have been reported on severe, often unexplained, honey bee mortality in the past (Kauffeld, Everitt, \& Taylor, 1976). Beekeepers also reported severe winter weather to be responsible for winter mortality in the US (van Engelsdorp, Hayes, Underwood, \& Pettis, 2008). Weather might be important for colony productivity as higher temperatures tend to increase colony productivity because of reduced metabolic demands on foragers (Harrison \& Fewell, 2002). The long periods of high temperatures and sufficient precipitation are both correlated to increased nectar production (Shuel, 1992), which in turn translates to increased colony productivity (Voorhies, Todd, \& Galbraith, 1933). Mainly, the severe winter weather is found for colony mortality.

\subsection{Loss of Genetic Diversity}

Honey bee genetic diversity derives from multiple mating of a single queen with multiple males (polyandry). At the colony level, genetic variability has been shown to be important for disease resistance, homeostasis, thermoregulation and overall colony fitness (Tarpy, 2003; Jones, Myerscough, Graham, \& Oldroyd, 2004; Graham, Myerscough, Jones, \& Oldroyd, 2006; Mattila \& Seeley, 2007). About 26 subspecies and numerous ecotypes of western honey bees (Apis mellifera) have been described, based upon behaviour, morphology, and molecular evidence and are grouped into five evolutionary lineages: A from Africa, $\mathrm{C}$ from the northern Mediterranean region and eastern Europe, $\mathrm{M}$ from northern and western Europe, $\mathrm{O}$ from the eastern Mediterranean and the Near and Middle East region, and Y from the east African country Ethiopia (Ruttner, 1988; Sheppard \& Meixner, 2003). The performance of colonies in a number of resistance traits against pest, parasites and diseases may be considered for apicultural interest (Meixner et al., 2010). Recent researches increasingly bring the development of traits related to colony vitality into focus which have introduced and evaluated additional traits related to colony vitality, such as hygienic behaviour, mite infestation development and overwintering ability. To increase genetic diversity, several European countries, especially those with a tradition 
in the production of the commercially most desirable races (A. m. ligustica and A. m. carnica), have coordinated national breeding schemes. From these programs, thousands of queens are produced and exported across Europe and the world (Lodesani \& Costa, 2003). The genetic variability of the US honey bee population is reduced compared to that of indigenous honey bee populations of Europe (Sheppard, 1988). In addition, it has been reported that as few as 500 breeder queens have been used to provide progeny for most of the commercial hives present in the US (Schiff \& Sheppard, 1995; Delaney, Meixner, Schiff, \& Sheppard, 2009). Lack of genetic diversity may be responsible for colony losses as the genetic similarity among colonies in wide areas increases the chances of successful disease transmission.

\subsection{Other Factors Associated with Honey Bee Decline}

In addition to the above mentioned drivers, there are other drivers like parasites, predators and competition from invasive non-native species of animals and plants in specific location. Ravoet et al. (2013) reported that the presence of the parasite Crithidia mellificae (Phylum-Euglenozoa and Class-Kinetoplastea) has effects on winter colony mortality. Sometimes, the environmental stresses may also be responsible for the decline of honey bees.

The exotic plants and land-use negatively affect specialized plant-pollinator interactions (Grass, Berens, Peter, \& Farwig, 2013). Invasive alien species of plants and insects, may have effects on native honey bees worldwide (Stout \& Morales, 2009). There is a need to determine the impacts of invasive animals, plants, parasites and pathogens on native honey bees.

\section{Conclusion and Future Directions}

The recent declines of honey bees can result in loss of pollination services leading to ecological and economic impacts. Due to the recent loss in these important pollinators, there is a need of some mitigation strategies for their loss and associated risks. The use of pesticides has a pronounced effects on bee health and colony populations. Additional factors like viruses, parasites, pathogens and lack of genetic diversity have remarkable effects on declining recent honey bee populations. These diverse threats to honey bees might interact and produce synergistic effects.

To reduce the ecological damage and loss, an understanding of the commercial and pollination needs of each country is needed to enable for pollination services which helps to maintain a sustainable level and reduce the risk of crop loss. Farmers can also practice agricultural techniques which can provide non-toxic methods of weed and pest control thus preventing the honey bees from harmful effects of pesticides and chemicals. Also, continued research in identifying the disease resistant ecotypes of honey bee is essential.

\section{References}

Aizen, M. A., Garibaldi, L. A., Cunningham, S. A., \& Klein, A. M. (2008). Long-term global trends in crop yield and production reveal no current pollination shortage but increasing pollinator dependency. Current Biology, 18, 1572-1575. http://dx.doi.org/10.1016/j.cub.2008.08.066

Alaux, C., Ducloz, F., Crauser, D., \& Le Conte, Y. (2010). Diet effects on honeybee immunocompetence. Biol. Lett., 6, 562-565. http://dx.doi.org/10.1098/rsbl.2009.0986

Allsopp, M. H., De Lange, W. J., \& Veldtman, R. (2008). Valuing insect pollination services with cost of replacement. PloS One, 3, e3128. http://dx.doi.org/ 10.1371/journal.pone.0003128

Antúnez, K., Martín-Hernández, R., Prieto, L., Meana, A., Zunino, P., \& Higes, M. (2009). Immune suppression in the honey bee (Apis mellifera) following infection by Nosema ceranae (Microsporidia). Environ. Microbiol., 11, 2284-2290. http://dx.doi.org/10.1111/j.1462-2920.2009.01953.x

Aston, D. (2010). Honey bee winter loss survey for England, 2007-8. J. Apic. Res., 2010.

Bacandritsos, N., Granato, A., Budge, G., Papanastasiou, I., Roinioti, E., ... Caldon, M. (2010). Sudden deaths and colony population decline in Greek honey bee colonies. $J$ Invertebr Pathol., 105, 335-340. http://dx.doi.org/10.1016/j.jip.2010.08.004

Bailey, L. (1956). Aetiology of European foul brood: A disease of the larval honey-bee. Nature, 178, 1130.

Bailey, L. (1957). The cause of European foul brood. Bee World, 38, 85-89.

Bailey, L. (1983). Melissococcus pluton, the cause of European foulbrood of honey bees (Apis spp.). J. Appl. Microbiol., 55, 65-69. http://dx.doi.org/10.1111/j.1365-2672.1983.tb02648.x

Ball, B. V. (1983). The association of Varroa jacobsoni with virus diseases of honey bees. Exp. Appl. Acarol., 19, 607-613. 
Ball, B. V., \& Allen, M. F. (1988). The prevalence of pathogens in honey bee (Apis mellifera) colonies infested with the parasitic mite Varroa jacobsoni. Ann. Appl. Biol., 113, 237-244. http://dx.doi.org/10.1111/j.1744-7348.1988.tb03300.x

Barnett, E. A., Charlton, A. J., \& Fletcher, M. R. (2007). Incidents of bee poisoning with pesticides in the United Kingdom, 1994-2003. Pest Manag Sci., 63, 1051-1057. http://dx.doi.org/10.1002/ps.1444

Barrett, S. C., Kohn, J. R., Falk, D. A., \& Holsinger, K. E. (1991). Genetic and evolutionary consequences of small population size in plants: Implications for conservation. Genetics and conservation of rare plants (pp. 3-30).

Bauer, D. M., \& Wing, I. S. (2010). Economic consequences of pollinator declines: A synthesis. Agr. Resource Econ. Rev., 39, 368-383.

Belloy, L., Imdorf, A., Fries, I., Forsgren, E., Berthoud, H., ... Kuhn, R. (2007). Spatial distribution of Melissococcus plutonius in adult honey bees collected from apiaries and colonies with and without symptoms of European foulbrood. Apidologie, 38, 136-140. http://dx.doi.org/10.1051/apido:2006069.

Bernal, J., Garrido-Bailon, E., Del Nozal, M. J., Gonzalez-Porto, A. V., Martin-Hernandez, R., ... Diego, J. C. (2010). Overview of pesticide residues in stored pollen and their potential effect on bee colony (Apis mellifera) losses in Spain. J. Econ. Entomol., 103, 1964-1971. http://dx.doi.org/10.1603/EC10235

Berthoud, H., Imdorf, A., Haueter, M., Radloff, S., \& Neumann, P. (2010). Virus infections and winter losses of honey bee colonies (Apis mellifera). J. Apic. Res., 49(1), 60-65. http://dx.doi.org/10.3896/IBRA.1.49.1.08

Biesmeijer, J. C., Roberts, S. P. M., Reemer, M., Ohlemuller, R., Edwards, M., ... Peeters, T. (2006). Parallel declines in pollinators and insect-pollinated plants in Britain and the Netherlands. Science, 313, 351-354. http://dx.doi.org/10.1126/science.1127863

Bortolotti, L., Sabatini, A. G., Mutinelli, F., Astuti, M., Lavazza, A., ... Piro, R. (2010). Spring honey bee losses in Italy. Julius-Kühn-Archiv, S-148.

Botias, C., Martín-Hernández, R., Dias, J., García-Palencia, P., Matabuena, M., ... Juarranz, A. (2012). The effect of induced queen replacement on Nosema spp. infection in honey bee (Apis mellifera iberiensis) colonies. Environ. Microbiol., 14, 845-859. http://dx.doi.org/10.1111/j.1462-2920.2011.02647.x

Bowen-Walker, P. L., Martin, S. J., \& Gunn, A. (1999). The Transmission of Deformed Wing Virus between Honeybees (Apis mellifera L.) by the Ectoparasitic Mite (Varroa jacobsoni Oud.). J Invertebr Pathol., 73, 101-106. http://dx.doi.org/10.1006/jipa.1998.4807

Brodschneider, R., \& Crailsheim, K. (2010). Nutrition and health in honey bees. Apidologie, 41, 278-294. http://dx.doi.org/10.1051/apido/2010012

Burgett, M., Daberkow, S., Rucker, R., \& Thurman, W. (2010). US pollination markets: Recent changes and historical perspective. Am. Bee. J.

Calderone, N. W. (2012). Insect Pollinated Crops, Insect Pollinators and US Agriculture: Trend Analysis of Aggregate Data for the Period 1992-2009. PloS One, 7, e37235. http://dx.doi.org/10.1371/journal.pone.0037235

Cane, J. H. (2001). Habitat fragmentation and native bees: A premature verdict? Conservation Ecology, 5, 3.

Cane, J. H., Minckley, R. L., Kervin, L. J., Roulston, T. H., \& Williams, N. M. (2006). Complex responses within a desert bee guild (Hymenoptera: Apiformes) to urban habitat fragmentation. Ecol. Appl., 16, 632-644. http://dx.doi.org/10.1890/1051-0761(2006)016[0632:CRWADB]2.0.CO;2

Caron, D. M. (2010). Bee colony pollination rental prices, eastern US with comparison to west coast. Retrieved from http:/maarec.cas.psu.edu/pdfs/Pollination-rentals.pdf

Carreck, N. L., Ball, B. V., \& Martin, S. J. (2010). Honey bee colony collapse and changes in viral prevalence associated with Varroa destructor. J. Apic. Res., 49, 93-94. http://dx.doi.org/10.3896/IBRA.1.49.1.13

Carreck, N. L., Williams, I. H., \& Little, D. J. (1997). The movement of honey bee colonies for crop pollination and honey production by beekeepers in Great Britain. Bee World, 78, 67-77.

Carvell, C., Roy, D. B., Smart, S. M., Pywell, R. F., Preston, C. D., \& Goulson, D. (2006). Declines in forage availability for bumblebees at a national scale. Biological Conservation, 132, 481-489. http://dx.doi.org/10.1016/j.biocon.2006.05.008 
Chauzat, M. P., Carpentier, P., Madec, F., Bougeard, S., Cougoule, N., ... Drajnudel, P. (2010). Role of infectious agents and parasites in the health of honey bee colonies in France. J. Apic. Res., 2010.

Chauzat, M. P., Faucon, J. P., Martel, A. C., Lachaize, J., Cougoule, N., \& Aubert, M. (2006). A survey of pesticide residues in pollen loads collected by honey bees in France. J. Econ. Entomol., 99, 253-262. http://dx.doi.org/10.1093/jee/99.2.253

Chen, Y., Evans, J. D., Smith, I. B., \& Pettis, J. S. (2008). Nosema ceranae is a long-present and wide-spread microsporidian infection of the European honey bee (Apis mellifera) in the United States. $J$ Invertebr Pathol., 97, 186-188. http://dx.doi.org/10.1016/j.jip.2007.07.010

Corbet, S. A., Williams, I. H., \& Osborne, J. L. (1991). Bees and the pollination of crops and wild flowers in the European Community. Bee world, 72, 47-59.

Cox-Foster, D., \& van Engelsdorp, D. (2009). Saving the honeybee. Scientific American Magazine, 300, 40-47. http://dx.doi.org/10.1038/scientificamerican0409-40

Cox-Foster, D. L., Conlan, S., Holmes, E. C., Palacios, G., Evans, J. D., Moran, N. A., ... Geiser, D. M. (2007). A metagenomic survey of microbes in honey bee colony collapse disorder. Science, 318, 283-287. http://dx.doi.org/10.1126/science.1146498

Crailsheim, K., Brodschneider, R., \& Neumann, P. (2009). The COLOSS puzzle: Filling in the gaps (pp. 3-4).

Cressey, D. (2013). Europe debates risk to bees. Nature, 496, 408. http://dx.doi.org/10.1038/497188a

Cresswell, J. E., \& Thompson, H. M. (2012). Comment on A common pesticide decreases foraging success and survival in honey bees. Science, 337, 1453. http://dx.doi.org/10.1126/science.1224618

Cunningham, S. A. (2000). Depressed pollination in habitat fragments causes low fruit set. Proc. R. Soc. London, Ser. B of London.Series B: Biological Sciences, 267, 1149-1152. http://dx.doi.org/ 10.1098/rspb.2000.1121

Currie, R. W., Pernal, S. F., \& Guzman-Novoa, E. (2010). Honey bee colony losses in Canada. J. Apic. Res., 49, 104-106. http://dx.doi.org/10.3896/IBRA.1.49.1.18

Dag, A., Zipori, I., \& Pleser, Y. (2006). Using bumblebees to improve almond pollination by the honeybee. $J$. Apic. Res., 45, 215-216.

Dahle, B. (2010). Role of Varroa destructor for honey bee colony losses in Norway. J. Apic. Res., 2010.

De Miranda, J. R., \& Fries, I. (2008). Venereal and vertical transmission of deformed wing virus in honeybees (Apis mellifera L.). J. Invertebr. Pathol., 98, 184-189. http://dx.doi.org/10.1016/j.jip.2008.02.004

De Miranda, J. R., Cordoni, G., \& Budge, G. (2010). The acute bee paralysis virus-Kashmir bee virus-Israeli acute paralysis virus complex. J. Invertebr. Pathol., 103, S30-S47. http://dx.doi.org/10.1016/j.jip.2009.06.014

Del Moral, R., \& Standley, L. A. (1979). Pollination of angiosperms in contrasting coniferous forests. American Journal of Botany, 26-35.

Delaney, D. A., Meixner, M. D., Schiff, N. M., \& Sheppard, W. S. (2009). Genetic characterization of commercial honey bee (Hymenoptera: Apidae) populations in the United States by using mitochondrial and microsatellite markers. Ann. Entomol. Soc. Am., 102, 666-673. http://dx.doi.org/10.1603/008.102.0411

Delaplane, K. K., \& Mayer, D. F. (2000). Crop pollination by bees. Cabi publishing, Wallingford, UK.

Delaplane, K. S., \& Hood, W. M. (1999). Economic threshold for Varroa jacobsoni Oud. in the southeastern USA. Apidologie, 30, 383-395.

Di Prisco, G., Zhang, X., Pennacchio, F., Caprio, E., Li, J., Evans, J. D., \& Chen, Y. P. (2011). Dynamics of Persistent and Acute Deformed Wing Virus Infections in Honey Bees. Apis mellifera. Viruses, 3, 2425-2441. http://dx.doi.org/10.3390/v3122425

Duan, J. J., Marvier, M., Huesing, J., Dively, G., \& Huang, Z. Y. (2008). A meta-analysis of effects of Bt crops on honey bees (Hymenoptera: Apidae). PloS One, 3, e1415. http://dx.doi.org/10.1371/journal.pone.0001415

Eischen, F. A., Graham, R. H., \& Cox, R. (2005). Regional distribution of Paenibacillus larvae subspecies larvae, the causative organism of American foulbrood, in honey bee colonies of the western United States. $J$. Econ. Entomol., 98, 1087-1093. http://dx.doi.org/10.1603/0022-0493-98.4.1087

Ellis, J., Evans, J. D., \& Pettis, J. (2010). Reviewing colony losses and Colony Collapse Disorder in the United 
States. J Apic Res, 49, 134-136.

Evans, J. D., \& Schwarz, R. S. (2011). Bees brought to their knees: Microbes affecting honey bee health. Trends in microbiology, 19(12), 614-620. http://dx.doi.org/10.1016/j.tim.2011.09.003

FAO. (2013). Food and Agriculture Organization of the United Nations. Retrieved from http://faostat.fao.org

Fisher, B., Turner, R. K., \& Morling, P. (2009). Defining and classifying ecosystem services for decision making. Ecol. Econ., 68, 643-653. http://dx.doi.org/10.1016/j.ecolecon.2008.09.014

Fairbrother, A., Purdy, J., Anderson, T., \& Fell, R. (2014). Risks of neonicotinoid insecticides to honeybees. Environmental Toxicology and Chemistry, 33, 719-731. http://dx.doi.org/0.1002/etc.2527

Forsgren, E. (2010). European foulbrood in honey bees. J Invertebr Pathol., 103, S5-S9. http://dx.doi.org/10.1016/j.jip.2009.06.016

Free, J. B. (1970). Insect pollination of crops. Insect pollination of crops.

Fries, I. (2010). Nosema ceranae in European honey bees (Apis mellifera). J Invertebr Pathol., 103, S73-S79. http://dx.doi.org/10.1016/j.jip.2009.06.017

Gajger, I. T., Vugrek, O., Grilec, D., \& Petrinec, Z. (2010). Prevalence and distribution of Nosema ceranae in Croatian honeybee colonies. Veterinarni medicina, 55, 457-462.

Gallai, N., Salles, J. M., Settele, J., \& Vaissiere, B. E. (2009). Economic valuation of the vulnerability of world agriculture confronted with pollinator decline. Ecological Economics, 68, 810-821. http://dx.doi.org/10.1016/j.ecolecon.2008.06.014

Genersch, E. (2010). American Foulbrood in honeybees and its causative agent, Paenibacillus larvae. J Invertebr Pathol., 103, S10-S19. http://dx.doi.org/10.1016/j.jip.2009.06.015

Genersch, E. (2010b). Honey bee pathology: Current threats to honey bees and beekeeping. Appl. Microbiol. Biotechnol., 87, 87-97.

Genersch, E., \& Aubert, M. (2010). Emerging and re-emerging viruses of the honey bee (Apis mellifera L.). Veterinary Research, 41, 54. http://dx.doi.org/10.1051/vetres/2010027

Genersch, E., Forsgren, E., Pentikäinen, J., Ashiralieva, A., Rauch, S., ... Kilwinski, J. (2006). Reclassification of Paenibacillus larvae subsp. pulvifaciens and Paenibacillus larvae subsp. larvae as Paenibacillus larvae without subspecies differentiation. Int. J. Syst. Evol. Microbiol., 56, 501-511. http://dx.doi.org/10.1099/ijs.0.63928-0

Ghazoul, J. (2005). Buzziness as usual? Questioning the global pollination crisis. Trends Ecol. Evol., 20, 367-373. http://dx.doi.org/10.1016/j.tree.2005.04.026

Giersch, T., Berg, T., Galea, F., \& Hornitzky, M. (2009). Nosema ceranae infects honey bees (Apis mellifera) and contaminates honey in Australia. Apidologie, 40, 117-123. http://dx.doi.org/10.1051/apido/2008065

Gill, R. A. (1990). The value of honeybee pollination to society. In VI International Symposium on Pollination 288 (pp. 62-68).

Graham, S., Myerscough, M. R., Jones, J. C., \& Oldroyd, B. P. (2006). Modelling the role of intracolonial genetic diversity on regulation of brood temperature in honey bee (Apis mellifera L.) colonies. Insectes Soc., 53, 226-232. http://dx.doi.org/10.1007/s00040-005-0862-5

Grass, I., Berens, D. G., Peter, F., \& Farwig, N. (2013). Additive effects of exotic plant abundance and land-use intensity on plant-pollinator interactions. Oecologia, 173, 913-923. http://dx.doi.org/10.1007/s00442-013-2688-6

Gray, A., Peterson, M., \& Teale, A. (2010). An update on recent colony losses in Scotland from a sample survey covering 2006-2008. J. Apic. Res. and Bee World, 49, 129-131. http://dx.doi.org/10.3896/IBRA.1.49.1.28

Gregory, P. G., Evans, J. D., Rinderer, T., \& De Guzman, L. (2005). Conditional immune-gene suppression of honeybees parasitized by Varroa mites. Journal of Insect Science, 5. http://dx.doi.org/10.1093/jis/5.1.7

Guzman-Novoa, E., Eccles, L., Calvete, Y., Mcgowan, J., Kelly, P. G., \& Correa-Benjtez, A. (2010). Varroa destructor is the main culprit for the death and reduced populations of overwintered honey bee (Apis mellifera) colonies in Ontario, Canada. Apidologie, 41, 443-450. http://dx.doi.org/10.1051/apido/2009076

Haddad, N., Bataeneh, A., Albaba, I., Obeid, D., \& Abdulrahman, S. (2009). Status of colony losses in the Middle East. Proceedings of the 41st Apimondia Congress Mointpellier, France (p. 36). 
Hails, R. S., Ball, B. V., \& Genersch, E. (2008). Infection strategies of insect viruses (pp. 255-276).

Harrison, J. F., \& Fewell, J. H. (2002). Environmental and genetic influences on flight metabolic rate in the honey bee. Apis mellifera. Comparative Biochemistry and Physiology-Part A: Mol. Integr. Physiol., 133, 323-333. http://dx.doi.org/10.1016/S1095-6433(02)00163-0

Harz, M., Muller, F., \& Rademacher, E. (2010). Organic acids: Acute toxicity on Apis mellifera and recovery in the haemolymph. J. Apic. Res., 2010.

Heithaus, E. R. (1974). The role of plant-pollinator interactions in determining community structure. Annals of the Missouri Botanical Garden, 61, 675-691.

Heywood, V. H. (1995). Global biodiversity assessment. Cambridge University Press.

Higes, M., Martin, R., \& Meana, A. (2006). Nosema ceranae, a new microsporidian parasite in honeybees in Europe. J Invertebr Pathol., 92, 93-95. http://dx.doi.org/10.1016/j.jip.2006.02.005

Higes, M., Martín-Hernández, R., Botias, C., Bailon, E. G., Gonzalez-Porto, A. V., ... Barrios, L. (2008). How natural infection by Nosema ceranae causes honeybee colony collapse. Environ. Microbiol., 10, 2659-2669. http://dx.doi.org/10.1111/j.1462-2920.2008.01687.x

Highfield, A. C., El Nagar, A., Mackinder, L. C., Laure, M., Hall, M. J., Martin, S. J., \& Schroeder, D. C. (2009). Deformed wing virus implicated in overwintering honeybee colony losses. Applied and Environ. Microbiol., 75, 7212-7220. http://dx.doi.org/10.1128/AEM.02227-09

Hines, H. M., \& Hendrix, S. D. (2005). Bumble bee (Hymenoptera: Apidae) diversity and abundance in tallgrass prairie patches: Effects of local and landscape floral resources. Environmental Entomology, 34, 1477-1484. http://dx.doi.org/10.1603/0046-225X-34.6.1477

Holden, C. (2006). Report warns of looming pollination crisis in North America. Science, $314,397$. http://dx.doi.org/10.1126/science.314.5798.397

Hopwood, J., Vaughan, M., Shepherd, M., Biddinger, D., Mader, E., Black, S. H., \& Mazzacano, C. (2012). Are Neonicotinoids Killing Bees? A review of research into the effects of neonicotinoid insecticides on bees, with recommendations for action. Xerces Society for Invertebrate Conservation, USA.

Huang, W. F., Jiang, J. H., Chen, Y. W., \& Wang, C. H. (2007). A Nosema ceranae isolate from the honeybee Apis mellifera. Apidologie, 38, 30-37.

Huang, Z. Y., Hanley, A. V., Pett, W. L., Langenberger, M., \& Duan, J. J. (2004). Field and semifield evaluation of impacts of transgenic canola pollen on survival and development of worker honey bees. J. Econ. Entomol., 97, 1517-1523. http://dx.doi.org/10.1603/0022-0493-97.5.1517

Hung, A. C., Adams, J. R., \& Shimanuki, H. (1995). Bee parasitic mite syndrome (II). The role of Varroa mite and viruses. Am. Bee. J., 135.

Huryn, V. M. B. (1997). Ecological impacts of introduced honey bees. Quarterly Review of Biology, $275-297$.

Ingram, M., Nabhan, G., \& Buchmann, S. L. (1996). Our forgotten pollinators: Protecting the birds and bees. Global Pesticide Campaigner, 6, 1-8.

Invernizzi, C., Abud, C., Tomasco, I. H., Harriet, J., Ramallo, G., Campa, J., ... Mendoza, Y. (2009). Presence of Nosema ceranae in honeybees (Apis mellifera) in Uruguay. J Invertebr Pathol., 101, 150-153. http://dx.doi.org/10.1016/j.jip.2009.03.006

Ivanova, E. N., \& Petrov, P. P. (2010). Regional differences in honey bee winter losses in Bulgaria during the period 2006-9. J. Apic. Res.

Johnson, R. M., Ellis, M. D., Mullin, C. A., \& Frazier, M. (2010). Pesticides and honey bee toxicity-USA. Apidologie, 41, 312-331. http://dx.doi.org/10.1051/apido/2010018

Jones, J. C., Myerscough, M. R., Graham, S., \& Oldroyd, B. P. (2004). Honey bee nest thermoregulation: diversity promotes stability. Science, 305, 402-404. http://dx.doi.org/10.1126/science.1096340

Kauffeld, N. M., Everitt, J. H., \& Taylor, E. A. (1976). Honey bee problems in the Rio Grande Valley of Texas. Am. Bee. J.

Kearns, C. A., \& Inouye, D. W. (1997). Pollinators, flowering plants, and conservation biology. Bioscience, 47, 297-307. 
Kevan, P. G., \& Viana, B. F. (2003). The global decline of pollination services. Biodiversity, 4, 3-8. http://dx.doi.org/10.1080/14888386.2003.9712703

Klee, J., Besana, A. M., Genersch, E., Gisder, S., Nanetti, A., \& Tam, D. Q. (2007). Widespread dispersal of the microsporidian Nosema ceranae, an emergent pathogen of the western honey bee, Apis mellifera. $J$ Invertebr Pathol., 96, 1-10. http://dx.doi.org/10.1016/j.jip.2007.02.014

Klein, A. M., Vaissiere, B. E., Cane, J. H., Steffan-Dewenter, I., Cunningham, S. A., ... Kremen, C. (2007). Importance of pollinators in changing landscapes for world crops. Proc. R. Soc. London, Ser. B: Biological Sciences, 274, 303-313. http://dx.doi.org/10.1098/rspb.2006.3721

Klein, A., Steffan-Dewenter, I., \& Tscharntke, T. (2003). Fruit set of highland coffee increases with the diversity of pollinating bees. Proc. R. Soc. London, Ser. B of London.Series B: Biological Sciences, 270, 955-961. http://dx.doi.org/10.1098/rspb.2002.2306

Kralj, J., Brockmann, A., Fuchs, S., \& Tautz, J. (2007). The parasitic mite Varroa destructor affects non-associative learning in honey bee foragers, Apis mellifera L. Journal of Comparative Physiology A, 193, 363-370. http://dx.doi.org/10.1007/s00359-006-0192-8

Kralj, J., \& Fuchs, S. (2006). Parasitic Varroa destructor mites influence flight duration and homing ability of infested Apis mellifera foragers. Apidologie, 37, 577-587. http://dx.doi.org/10.1051/apido:2006040

Kremen, C., Williams, N. M., Bugg, R. L., Fay, J. P., \& Thorp, R. W. (2004). The area requirements of an ecosystem service: Crop pollination by native bee communities in California. Ecology Letters, 7 , 1109-1119. http://dx.doi.org/10.1111/j.1461-0248.2004.00662.x

Kremen, C., Williams, N. M., \& Thorp, R. W. (2002). Crop pollination from native bees at risk from agricultural intensification. PNAS, 99, 16812-16816. http://dx.doi.org/10.1073/pnas.262413599

Laurent, F. M., \& Rathahao, E. (2003). Distribution of imidacloprid in sunflowers (Helianthus annuus L.) following seed treatment. J. Agric. Food. Chem., 51, 8005-8010. http://dx.doi.org/10.1021/jf034310n

Le Conte, Y., \& Navajas, M. (2008). Climate change: impact on honey bee populations and diseases. Revue Scientifique et Technique-Office International des Epizooties, 27, 499-510.

Levin, M. D. (1983). Value of bee pollination to US agriculture. Bulletin of the ESA, 29, 50-51. http://dx.doi.org/10.1093/besa/29.4.50

Lodesani, M., \& Costa, C. (2003). Bee breeding and genetics in Europe. Bee World, 84, 69-85.

Maini, S., Medrzycki, P., \& Porrini, C. (2010). The puzzle of honey bee losses: a brief review. Bulletin of Insectology, 63, 153-160.

Maori, E., Paldi, N., Shafir, S., Kalev, H., Tsur, E., ... Glick, E. (2009). IAPV, a bee affecting virus associated with Colony Collapse Disorder can be silenced by dsRNA ingestion. Insect Mol. Biol., 18, 55-60. http://dx.doi.org/10.1111/j.1365-2583.2009.00847.x

Martin, S. J. (2001). The role of Varroa and viral pathogens in the collapse of honeybee colonies: a modelling approach. J. Appl. Ecol., 38, 1082-1093. http://dx.doi.org/10.1046/j.1365-2664.2001.00662.x

Martin, S. J., Ball, B. V., \& Carreck, N. L. (2010). Prevalence and persistence of deformed wing virus (DWV) in untreated or acaricide-treated Varroa destructor infested honey bee (Apis mellifera) colonies. J. Apic. Res., 49, 72-79. http://dx.doi.org/ 10.3896/IBRA.1.49.1.10

Marvier, M., McCreedy, C., Regetz, J., \& Kareiva, P. (2007). A meta-analysis of effects of Bt cotton and maize on nontarget invertebrates. Science, 316, 1475-1477. http://dx.doi.org/10.1126/science.1139208

Matheson, A. (1993). World bee health report. Bee World, 74.

Mattila, H. R., \& Seeley, T. D. (2007). Genetic diversity in honey bee colonies enhances productivity and fitness. Science, 317, 362-364. http://dx.doi.org/10.1126/science.1143046

Maxim, L., \& van der Sluijs, J. (2013). Seed-dressing systemic insecticides and honeybees. Late Lessons from Early Warnings (pp. 401-438). Science, Precaution, Innovation European Environment Agency (EEA).

McGregor, S. E. (1976). Insect pollination of cultivated crop plants. Agricultural Research Service, US Department of Agriculture.

Mckee, B. A., Goodman, R. D., \& Hornitzky, M. A. (2004). The transmission of European foulbrood (Melissococcus plutonius) to artificially reared honey bee larvae (Apis mellifera). J. Apic. Res., 43, 93-100. 
Meixner, M. D., Costa, C., Kryger, P., Hatjina, F., Bouga, M., ... Ivanova, E. (2010). Conserving diversity and vitality for honey bee breeding. J. Apic. Res., 49, 85-92. http://dx.doi.org/10.3896/IBRA.1.49.1.12

Mishra, A., Afik, O., Cabrera, M. L., Delaplane, K. S., \& Mowrer, J. E. (2013). Inorganic Nitrogen Derived from Foraging Honey Bees Could Have Adaptive Benefits for the Plants They Visit. PloS One, 8, e70591. http://dx.doi.org/10.1371/journal.pone.0070591

Morse, R. A., \& Calderone, N. W. (2000). The value of honey bees as pollinators of US crops in 2000. Bee Culture, 128, 1-15.

Mullin, C. A., Frazier, M., Frazier, J. L., Ashcraft, S., Simonds, R., \& Pettis, J. S. (2010). High levels of miticides and agrochemicals in North American apiaries: implications for honey bee health. PloS One, 5, e9754. http://dx.doi.org/10.1371/journal.pone.0009754

Nabhan, G. P., \& Buchmann, S. L. (1996). Pesticide disruption of interactions between rare plants and their pollinators: Chemically induced habitat fragmentation in the United States-Mexico borderlands? Comments on Toxicology, 5, 475-486.

National Research Council \& National Academies Press. (2007). Status of pollinators in North America. Natl Academy Pr.

Naug, D. (2009). Nutritional stress due to habitat loss may explain recent honeybee colony collapses. Biological Conservation, 142, 2369-2372. http://dx.doi.org/10.1016/j.biocon.2009.04.007

Oldroyd, B. P. (2007). What's killing American honey bees? PLoS Biology, 5, e168. http://dx.doi.org/10.1371/journal.pbio.0050168

Oldroyd, B. P., \& Nanork, P. (2009). Conservation of Asian honey bees. Apidologie, 40, 296-312. http://dx.doi.org/10.1051/apido/2009021

Ollerton, J., Winfree, R., \& Tarrant, S. (2011). How many flowering plants are pollinated by animals? Oikos, 120, 321-326. http://dx.doi.org/10.1111/j.1600-0706.2010.18644.x

Olmstead, A. L., \& Wooten, D. B. (1987). Bee pollination and productivity growth: the case of Alfalfa. American Journal of Agricultural Economics, 69, 56-63. http://dx.doi.org/10.2307/1241306

Parker, F. D., Batra, S. W. T., \& Tependino, V. J. (1987). New pollinators for our crops. Agri.Zool.Rev., 2.

Pauw, A., \& Hawkins, J. A. (2011). Reconstruction of historical pollination rates reveals linked declines of pollinators and plants. Oikos, 120, 344-349. http://dx.doi.org/10.1111/j.1600-0706.2010.19039.x

Paxton, R. J. (2010). Does infection by Nosema ceranae causes Colony Collapse Disorder in honey bees (Apis mellifera). J. Apic. Res., 49, 80-84. http://dx.doi.org/10.3896/IBRA.1.49.1.11

Paxton, R. J., Klee, J., Korpela, S., \& Fries, I. (2007). Nosema ceranae has infected Apis mellifera in Europe since at least 1998 and may be more virulent than Nosema apis. Apidologie, 38, 558-565. http://dx.doi.org/10.1051/apido:2007037

Pedersen, K., \& Omholt, S. W. (1993). A comparison of diets for honeybee. Norwegian Journal of Agricultural Sciences, 7.

Pettis, J. S., \& Delaplane, K. S. (2010). Coordinated responses to honey bee decline in the USA. Apidologie, 41, 256-263. http://dx.doi.org/10.1051/apido/2010013

Pettis, J. S., Lichtenberg, E. M., Andree, M., Stitzinger, J., \& Rose, R. (2013). Crop pollination exposes honey bees to pesticides which alters their susceptibility to the gut pathogen Nosema ceranae. PloS One, 8 , e70182. http://dx.doi.org/10.1371/journal.pone.0070182

Potts, S. G., Biesmeijer, J. C., Kremen, C., Neumann, P., Schweiger, O., \& Kunin, W. E. (2010). Global pollinator declines: trends, impacts and drivers. Trends in Ecology \& Evolution, 25, 345-353. http://dx.doi.org/10.1016/j.tree.2010.01.007

Potts, S. G., Roberts, S. P., Dean, R., Marris., G., Brown, M., Jones, R., \& Settele, J. (2009). Declines of managed honey bees and beekeepers in Europe. Journal of Apicultural Research, 49, 15-22. http://dx.doi.org/10.3896/IBRA.1.49.1.02

Potts, S. G., Vulliamy, B., Roberts, S., O’Toole, C., Dafni, A., ... Ne'eman, G. (2005). Role of nesting resources in organising diverse bee communities in a Mediterranean landscape. Ecol. Entomol., 30, 78-85. http://dx.doi.org/10.1111/j.0307-6946.2005.00662.x 
Rader, R., Howlett, B. G., Cunningham, S. A., Westcott, D. A., Newstrom-Lloyd, L. E., ... Walker, M. K. (2009). Alternative pollinator taxa are equally efficient but not as effective as the honeybee in a mass flowering crop. J. Appl. Ecol., 46, 1080-1087. http://dx.doi.org/10.1111/j.1365-2664.2009.01700.x

Rathcke, B. J. (1993). Habitat fragmentation and plant-pollinator. Current Science, 65.

Ravoet, J., Maharramov, J., Meeus, I., De Smet, L., Wenseleers, T., ... Smagghe, G. (2013). Comprehensive bee pathogen screening in Belgium reveals Crithidia mellificae as a new contributory factor to winter mortality. PloS One, 8. http://dx.doi.org/10.1371/journal.pone.0072443

Richards, A. J. (2001). Does low biodiversity resulting from modern agricultural practice affect crop pollination and yield? Ann. Bot., 88, 165-172. http://dx.doi.org/10.1006/anbo.2001.1463

Richards, K. W. (1996). Comparative efficacy of bee species for pollination of legume seed crops. Linnean society symposium series (Vol. 18). Academic press limited.

Robinson, W. S., Nowogrodzki, R., \& Morse, R. A. (1989). The value of honey bees as pollinators of US crops. II. Am. Bee. J., 129.

Roetschi, A., Berthoud, H., Kuhn, R., \& Imdorf, A. (2008). Infection rate based on quantitative real-time PCR of Melissococcus plutonius, the causal agent of European foulbrood, in honeybee colonies before and after apiary sanitation. Apidologie, 39, 362-371. http://dx.doi.org/10.1051/apido:200819

Rose, R., Dively, G. P., \& Pettis, J. (2007). Effects of Bt corn pollen on honey bees: emphasis on protocol development. Apidologie, 38, 368-377. http://dx.doi.org/10.1051/apido:2007022

Ruttner, F. (1988). Biogeography and taxonomy of honeybees. Springer-Verlag.

Santrac, V., Granato, A., \& Mutinelli, F. (2010). Detection of Nosema ceranae in Apis mellifera from Bosnia and Herzegovina. J. Apic. Res., 49, 100-101. http://dx.doi.org/10.3896/IBRA.1.49.1.16

Schiff, N. M., \& Sheppard, W. S. (1995). Genetic analysis of commercial honey bees (Hymenoptera: Apidae) from the southeastern United States. J. Econ. Entomol., 88, 1216-1220. http://dx.doi.org/10.1093/jee/88.5.1216

Sheppard, W. S. (1988). Comparative study of enzyme polymorphism in United States and European honey bee (Hymenoptera: Apidae) populations. Ann. Entomol. Soc. Am., 81, 886-889. http://dx.doi.org/10.1093/aesa/81.6.886

Sheppard, W. S., \& Meixner, M. D. (2003). Apis mellifera pomonella, a new honey bee subspecies from Central Asia. Apidologie, 34, 367-376. http://dx.doi.org/10.1051/apido:2003037

Shuel, R. W. (1992). The production of nectar and pollen. The hive and the honey bee. Hamilton, IL: Dadant, 401-436.

Southwick, E. E., \& Southwick Jr, L. (1992). Estimating the economic value of honey bees (Hymenoptera: Apidae) as agricultural pollinators in the United States. J. Econ. Entomol., 85, 621-633. http://dx.doi.org/10.1093/jee/85.3.621

Spivak, M., Mader, E., Vaughan, M., \& Euliss Jr, N. H. (2010). The Plight of the Bees. Environ. Sci. Technol., 45, 34-38. http://dx.doi.org/10.1021/es101468w

Steffan-Dewenter, I., Klein, A. M., Gaebele, V., Alfert, T., \& Tscharntke, T. (2006). Bee diversity and plant-pollinator interactions in fragmented landscapes. Specialization and Generalization in Plant-Pollinator Interactions, 387-410.

Steffan-Dewenter, I., Potts, S. G., \& Packer, L. (2005). Pollinator diversity and crop pollination services are at risk. Trends Ecol. Evol., 20, 651-652. http://dx.doi.org/10.1016/j.tree.2005.09.004

Stout, J. C., \& Morales, C. L. (2009). Ecological impacts of invasive alien species on bees. Apidologie, 40, 388-409. http://dx.doi.org/10.1051/apido:2009023

Sumner, D. A., \& Boriss, H. (2006). Bee-conomics and the leap in pollination fees. Agricultural and Resource Economics Update, 9, 9-11.

Tarpy, D. R. (2003). Genetic diversity within honeybee colonies prevents severe infections and promotes colony growth. Proc. R. Soc. London, Series B: Biological Sciences, 270, 99-103. http://dx.doi.org/10.1098/rspb.2002.2199 
Thomas, C. D., Cameron, A., Green, R. E., Bakkenes, M., Beaumont, L. J., ... Collingham, Y. C. (2004). Extinction risk from climate change. Nature, 427, 145-148. http://dx.doi.org/10.1038/nature02121

Thompson, H. M., \& Thorbahn, D. (2010). Review of honeybee pesticide poisoning incidents in Europe-evaluation of the hazard quotient approach for risk assessment. Julius-Kühn-Archiv, S-103.

Todd, J. H., De Miranda, J. R., \& Ball, B. V. (2007). Incidence and molecular characterization of viruses found in dying New Zealand honey bee (Apis mellifera) colonies infested with Varroa destructor. Apidologie, 38, 354-367. http://dx.doi.org/10.1051/apido:2007021

Tomkies, V., Flint, J., Johnson, G., Waite, R., Wilkins, S., ... Danks, C. (2009). Development and validation of a novel field test kit for European foulbrood. Apidologie, 40, 63-72. http://dx.doi.org/10.1051/apido: 2008060

Topolska, G., Gajda, A., Pohorecka, K., Bober, A., Kasprzak, S., ... Skubida, M. (2010). Winter colony losses in Poland. J. Apic. Res. http://dx.doi.org/10.3896/IBRA.1.49.1.27

Traver, B. E., \& Fell, R. D. (2011). Prevalence and infection intensity of Nosema in honey bee (Apis mellifera L.) colonies in Virginia. J Invertebr Pathol., 107, 43-49. http://dx.doi.org/10.1016/j.jip.2011.02.003

Van der Sluijs, J. P., Simon-Delso, N., Goulson, D., Maxim, L., Bonmatin, J. M., \& Belzunces, L. P. (2013). Neonicotinoids, bee disorders and the sustainability of pollinator services. Curr Opin Environ Sustain, 5, 293-305. http://dx.doi.org/10.1016/j.cosust.2013.05.007

Van der Zee, Re., Pisa, L., Andonov, S., Brodschneider, R., Charriere, J. D., ... Chlebo, R. (2012). Managed honey bee colony losses in Canada, China, Europe, Israel and Turkey, for the winters of 2008-9 and 1009-10. J. Apic. Res. and Bee World, 51, 100-114. http://dx.doi.org/10.3896/IBRA.1.51.1.12

Van Engelsdorp, D., Underwood, R., Caron, D., \& Hayes Jr, J. (2007). Estimate of managed colony losses in the winter of 2006-2007: A report commissioned by the Apiary Inspectors of America. American Bee Journal, 147, 599-603.

Van Engelsdorp, D., Hayes, J., Underwood, R. M., \& Pettis, J. (2008). A survey of honey bee colony losses in the US, fall 2007 to spring 2008. PloS One, 3, e4071. http://dx.doi.org/10.1371/journal.pone.0004071

Van Engelsdorp, D., \& Meixner, M. D. (2010). A historical review of managed honey bee populations in Europe and the United States and the factors that may affect them. J Invertebr Pathol., 103, S80-S95. http://dx.doi.org/10.1016/j.jip.2009.06.011

Veddeler, D., Olschewski, R., Tscharntke, T., \& Klein, A. M. (2008). The contribution of non-managed social bees to coffee production: new economic insights based on farm-scale yield data. Agroforestry Systems, 73, 109-114. http://dx.doi.org/10.1007/s10457-008-9120-y

Vejsnaes, F., Nielsen, S. L., \& Kryger, P. (2010). Factors involved in the recent increase in colony losses in Denmark. J. Apic. Res., 49, 109-110.

Voorhies, E. C., Todd, F. E., \& Galbraith, J. K. (1933). Economic aspects of the bee industry (5th ed.). University of California Press.

Westerkamp, C., \& Gottsberger, G. (2002). The costly crop pollination crisis. In P. Kevan \& V. Imperatriz Fonseca (Eds.), Pollinating Bees-The Conservation Link between Agriculture and Nature (pp. 51-56). Brasilia: Ministry of Environment.

Wilkins, S., Brown, M. A., \& Cuthbertson, A. G. (2007). The incidence of honey bee pests and diseases in England and Wales. Pest Manag Sci., 63, 1062-1068. http://dx.doi.org/10.1002/ps.1461

Williams, G. R., Shafer, A., Rogers, R. E., Shutler, D., \& Stewart, D. T. (2008). First detection of Nosema ceranae, a microsporidian parasite of European honey bees (Apis mellifera), in Canada and central USA. $J$ Invertebr Pathol., 97, 189-192. http://dx.doi.org/10.1016/j.jip.2007.08.005

Williams, I. H. (1994). The dependence of crop production within the European Union on pollination by honey bees. Agricultural Zoology Reviews.

Winfree, R., Aguilar, R., Vazquez, D. P., LeBuhn, G., \& Aizen, M. A. (2009). A meta-analysis of bees' responses to anthropogenic disturbance. Ecology, 90, 2068-2076.

Winston, M. L., \& Scott, C. D. (1984). The value of bee pollination to Canadian apiculture. Canadian Beekeeper., 11.

Wu, J. Y., Anelli, C. M., \& Sheppard, W. S. (2011). Sub-lethal effects of pesticide residues in brood comb on worker honey bee (Apis mellifera) development and longevity. PloS One, 6, e14720. 
http://dx.doi.org/10.1371/journal.pone.00014720

Yang, X., \& Cox-Foster, D. (2007). Effects of parasitization by Varroa destructor on survivorship and physiological traits of Apis mellifera in correlation with viral incidence and microbial challenge. Parasitology, 134, 405. http://dx.doi.org/10.1017/S0031182006000710

Yang, X., \& Cox-Foster, D. L. (2005). Impact of an ectoparasite on the immunity and pathology of an invertebrate: Evidence for host immunosuppression and viral amplification. Proc. Natl. Acad. Sci., 102, 7470-7475. http://dx.doi.org/10.1073/pnas.0501860102

Yue, C., Schroder, M., Gisder, S., \& Genersch, E. (2007). Vertical-transmission routes for deformed wing virus of honeybees (Apis mellifera). Journal of General Virology, 88, 2329-2336. http://dx.doi.org/10.1099/vir.0.83101-0

Zee, R. (2010). Colony losses in the Netherlands. J. Apic. Res., 49, 121-123.

\section{Copyrights}

Copyright for this article is retained by the author(s), with first publication rights granted to the journal.

This is an open-access article distributed under the terms and conditions of the Creative Commons Attribution license (http://creativecommons.org/licenses/by/3.0/). 